\title{
Production and Characterization of Polyhydroxyalkanoates and Native Microorganisms Synthesized from Fatty Waste
}

\author{
Javier Ricardo Gómez Cardozo, ${ }^{1}$ Amanda Lucía Mora Martínez, \\ María Yepes Pérez, ${ }^{2}$ and Guillermo Antonio Correa Londoño ${ }^{3}$ \\ ${ }^{1}$ Área Curricular de Biotecnología, Universidad Nacional de Colombia, Sede Medellín, Medellín, Colombia \\ ${ }^{2}$ Escuela de Química, Facultad de Ciencias, Universidad Nacional de Colombia, Sede Medellín, Medellín, Colombia \\ ${ }^{3}$ Departamento de Ciencias Agronómicas, Facultad de Ciencias Agrarias, Universidad Nacional de Colombia, \\ Sede Medellín, Medellín, Colombia
}

Correspondence should be addressed to Javier Ricardo Gómez Cardozo; jrgomez@unal.edu.co and Amanda Lucía Mora Martínez; almora@unal.edu.co

Received 28 August 2015; Accepted 4 January 2016

Academic Editor: Antonio Teixeira

Copyright (c) 2016 Javier Ricardo Gómez Cardozo et al. This is an open access article distributed under the Creative Commons Attribution License, which permits unrestricted use, distribution, and reproduction in any medium, provided the original work is properly cited.

\begin{abstract}
Polyhydroxyalkanoates (PHAs) are biodegradable and biocompatible plastics. They are synthesized by a wide variety of microorganisms (i.e., fungi and bacteria) and some organisms such as plants, which share characteristics with petrochemical-based plastics. The most recent studies focus on finding inexpensive substrates and extraction strategies that allow reducing product costs, thus moving into a widespread market, the market for petroleum-based plastics. In this study, the production of polyhydroxybutyrate (PHB) was evaluated using the native strains, Bacillus megaterium, Bacillus sp., and Lactococcus lactis, and glycerol reagent grade (GRG), residual glycerol (RGSB) byproduct of biodiesel from palm oil, Jatropha oil, castor oil, waste frying oils, and whey as substrates. Different bacteria-substrate systems were evaluated thrice on a laboratory scale under different conditions of temperature, $\mathrm{pH}$, and substrate concentration, employing $50 \mathrm{~mL}$ of broth in $250 \mathrm{~mL}$. The bacterial growth was tested in all systems; however, the $B$. megaterium GRG system generated the highest accumulation of PHA. The previous approach was allowed to propose a statistical design optimization with RGSB (i.e., RGSB, $15 \mathrm{~g} / \mathrm{L}, \mathrm{pH} 7.0$, and $25^{\circ} \mathrm{C}$ ). This system reached $2.80 \mathrm{~g} / \mathrm{L}$ of PHB yield and was the optimal condition tested; however, the optimal biomass $5.42 \mathrm{~g} / \mathrm{L}$ occurs at $\mathrm{pH} 9.0$ and $25^{\circ} \mathrm{C}$, with a substrate concentration of $22 \mathrm{~g} / \mathrm{L}$.
\end{abstract}

\section{Introduction}

Biopolymers are macromolecules produced by living cells from renewable sources, which give rise to known biodegradable plastics and therefore can be an alternative to solve environmental and social problems generated by the plastics industry from petrochemicals.

The petroleum-based plastics are highly resistant to temperature, pressure, chemical solvents, UV light, among other factors, which are widely employed in all fields of industry. For example, while in 19501.5 million ton (mTon) of plastics was produced, in contrast in $2010250 \mathrm{mTon}$ is reported and is expected to reach $330 \mathrm{mTon} 2015$ [1]. The plastics production scale (with an annual increase close to $6.5 \%$ during the next 5 years) is exponential accumulation of plastic waste in the environment [2] and pollution of water bodies and soils. This has a negative impact on human health, turning them into a social problem of high interest [3].

Therefore, researchers around the world have focused on the production of biodegradable polymers in the recent decades, using different methods and procedures, mainly in the family of the polyhydroxyalkanoates (PHA) and its derivatives thereof (e.g., polylactic polyesters aliphatic, polysaccharides) [4].

PHAs are biodegradable biopolyesters completely synthesized and catabolized by a wide range of microorganisms (i.e., bacteria and fungi) and some plants $[5,6]$. The bacterial PHA is intracellularly synthesized as cytoplasmic bodies hydrophobics, usually in excess of carbon source and deficiency of other essential nutrients, such as $\mathrm{O}, \mathrm{N}, \mathrm{P}, \mathrm{S}$, 

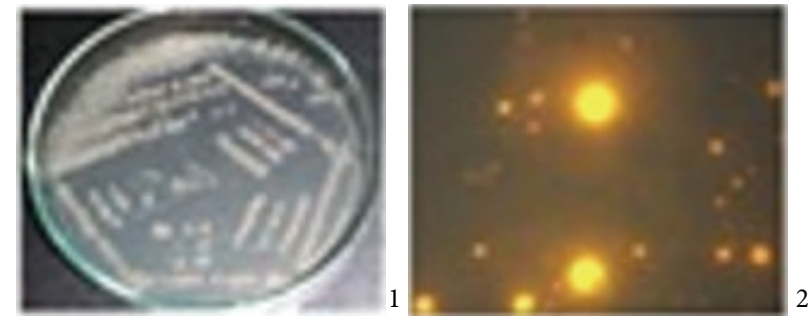

(a)

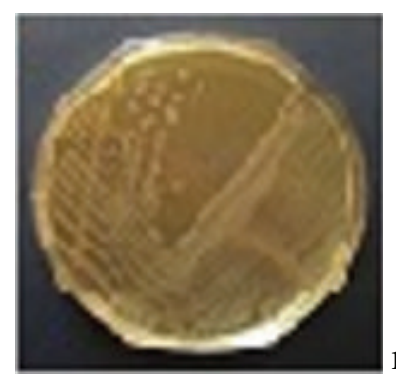

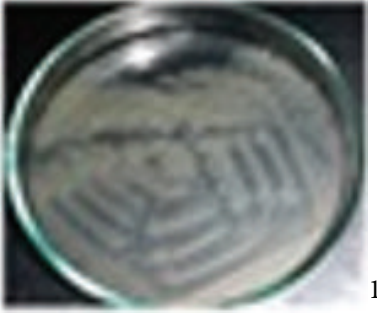

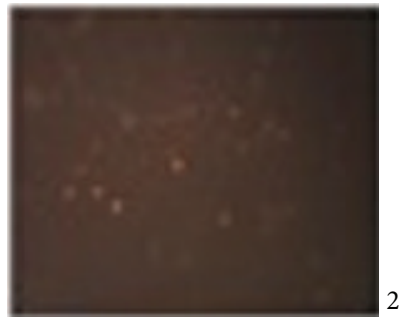

(b)

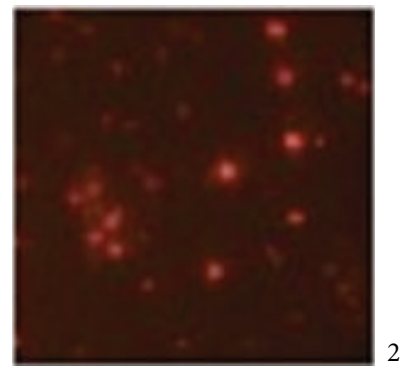

(c)

Figure 1: Macro- and microscopic morphology of the colonies of strains: (a) B. megaterium, (b) Bacillus sp., (c) L. lactis. 1, macroscopic characteristics of the colonies, 2, fluorescence microscopy at $450 \mathrm{~nm}$ with Blue Nile $[23,24]$.

or $\mathrm{Mg}$ [7]. However, the production cost is relatively higher compared to their petrochemical analogs, which have limited the industrial production of PHA. For example, the cost of production of $\mathrm{PHB}$ (one of the most studied type of PHA) was estimated at US $7.8-11.2 / \mathrm{kg}$, which corresponds to $30-40 \%$ carbon source; values exceed the prices of similar polymers obtained from oil (i.e., US 1.45 per kilogram in 2014) [2, 8, 9].

It clear that seeking a profitable production on an industrial scale depends on several factors such as the ability of the microorganism to employ a source of inexpensive carbon (recently, attention has focused on farm wastes and industrial byproducts), cost of the means of culture, growth rate, polymer synthesis speed, quality and quantity of PHA, and the cost of subsequent processes for the production of plastic [2, 9]. Furthermore, huge efforts are focused on finding renewable and inexpensive raw materials $[10,11]$, in the evaluation of genetically modified organisms [12], in the use of microbial consortia $[13,14]$ to reach improvements in the process of extraction and purification [15-17], in the development of technologies in transgenic plants [18, 19], and in the variation in strategies fermentation process (i.e., batch, fed batch, and continuous) [20-22].

In Colombia several companies (e.g., food and energy) generating products that can be exploited as potential sources of carbon in the production of PHAs exist. Thus, this study was focused on evaluating the potential of native strains for producing PHAs [25-27] from inexpensive substrates, waste, or byproducts from different industries (i.e., Jatropha oil, castor oil, waste frying oil, whey, and residual glycerol).

\section{Materials and Methods}

2.1. Bacterial Strains. Three native strains were employed in this study (Figure 1) from Collection of PROBIOM
(Production Structure and Application of Biomolecules) research group, isolated from different industrial waste, and selected based on biochemical, molecular, and analytical tests for their ability to produce PHA.

(i) Bacillus megaterium and Bacillus sp. were isolated from soil contaminated with sisal juice by Sánchez Moreno et al. [28], employing microbiological (serial dilutions), molecular (PCR amplification and sequencing of a portion of the small subunit $16 \mathrm{~S}$ rDNA), and chemical techniques (determination of PHA monomers by GC/MS), to characterize and determine potential strains in biopolymer synthesis.

(ii) Lactococcus lactis was isolated from whey by Cardona et al. [29], employing microbiological (serial dilutions), molecular (PCR amplification and sequencing of a portion of the small subunit $16 \mathrm{~S}$ rDNA), and chemical techniques (determination of PHA monomers by $\mathrm{GC} / \mathrm{MS}$ ), to characterize and determine potential strain in biopolymer synthesis.

The potential of the strains to produce PHA from sugar waste was evaluated by Salazar [23].

2.2. Culture Media. Several culture media supplemented with carbon sources of different nature and origin (i.e., Jatropha oil, castor oil, waste oil frying, whey, glycerol, and residual glycerol) were tested with each microorganism.

2.2.1. Whey Culture Medium as a Carbon Source. Minimal Salts Medium (MSM) was supplemented with $\mathrm{KH}_{2} \mathrm{PO}_{4} 1.2 \mathrm{~g} / \mathrm{L}$, $\mathrm{Na}_{2} \mathrm{HPO}_{4} \cdot 12 \mathrm{H}_{2} \mathrm{O} \quad 11.0 \mathrm{~g} / \mathrm{L} \quad \mathrm{NH}_{4} \mathrm{Cl} 16 \mathrm{~g} / \mathrm{L}, \quad \mathrm{MgSO}_{4} \cdot 7 \mathrm{H}_{2} \mathrm{O}$ $1.4 \mathrm{~g} / \mathrm{L}, 1 \mathrm{~mL}$ of trace element solution, $\mathrm{FeSO}_{4} \cdot 7 \mathrm{H}_{2} \mathrm{O} 10 \mathrm{~g} / \mathrm{L}$, $\mathrm{ZnSO}_{4} \cdot 7 \mathrm{H}_{2} \mathrm{O} 2.25 \mathrm{~g} / \mathrm{L}, \mathrm{CuSO}_{4} \cdot 5 \mathrm{H}_{2} \mathrm{O} 1.0 \mathrm{~g} / \mathrm{L}, \mathrm{MgSO}_{4} \cdot 5 \mathrm{H}_{2} \mathrm{O}$ 
TABLE 1: Fatty acid composition (\%) of Jatropha and castor oils [3032].

\begin{tabular}{lccc}
\hline & \multicolumn{3}{c}{ Oil } \\
\% Fatty acids & {$[30]$} & {$[31]$} & {$[32]$} \\
\hline Saturated & $<0.1$ & 0.1 & - \\
Myristic C14:0 & $13.2-13.54$ & 12.11 & $1.0-2.0$ \\
Palmitic C16:0 & $0.1-0.11$ & - & \\
Margaric C17:0 & $7.23-7.34$ & 6.02 & $1.0-1.5$ \\
Stearic C18:0 & - & - & $0.7-1.0$ \\
Dihydroxystearic C18:0 & $0.2-0.22$ & - & - \\
Arachidic C20:0 & $<0.1$ & - & - \\
Behenic C22:0 & $<0.1$ & - & - \\
Lignoceric C24:0 & & & \\
Unsaturated & $0.76-0.81$ & 0.75 & - \\
Palmitoleic C16:1 & - & - & $85.0-89.5$ \\
Ricinoleic C18:1 & $47.04-48.17$ & 35.74 & $3.0-3.5$ \\
Oleic C18:1 & $<0.1$ & - & $0.3-0.5$ \\
Eicosenoic 20:1 & $29.17-30.41$ & 44.93 & $3.0-4.2$ \\
Linoleic C18:2 & $0.2-0.22$ & 0.34 & $0.2-0.8$ \\
Linolenic C18:3 & & &
\end{tabular}

$0.5 \mathrm{~g} / \mathrm{L}, \quad \mathrm{CaCl}_{2} \cdot 2 \mathrm{H}_{2} \mathrm{O} \quad 2.0 \mathrm{~g} / \mathrm{L}, \quad \mathrm{Na}_{2} \mathrm{~B}_{4} \mathrm{O}_{7} \cdot 10 \mathrm{H}_{2} \mathrm{O} \quad 0.23 \mathrm{~g} / \mathrm{L}$, $\left(\mathrm{NH}_{4}\right)_{6} \mathrm{Mo}_{7} \mathrm{O}_{24} 0.1 \mathrm{~g} / \mathrm{L}, 10 \mathrm{~mL}$ of $\mathrm{HCl} 35 \%$, and whey $20 \mathrm{~g} / \mathrm{L}$. The medium was supplemented with yeast extract $(1 \mathrm{~g} / \mathrm{L})$ and adjusted to $\mathrm{pH}$ 7.0.

To avoid the eventual presence of proteins, the broth was acidified with $\mathrm{HCl}$ till $\mathrm{pH}$ values were lower than 4.0, prior to the addition of the whey, and thereafter it was sterilized. When the whey reached room temperature, it was centrifuged at $10,000 \mathrm{rpm}$ for $15 \mathrm{~min}$. The supernatant was filtered to remove floating particles, by fast filter paper Whatman (Red Band, Grade 589/3, diameter $125 \mathrm{~mm}$ ). The volume concentration was adjusted at $20 \mathrm{~g} / \mathrm{L}$ in the culture medium [24].

2.2.2. Culture Media Oils (Castor, Jatropha, and Waste Frying) as Carbon Sources. For growth of bacterial strains MSM was employed containing $\mathrm{KH}_{2} \mathrm{PO}_{4} 1.2 \mathrm{~g} / \mathrm{L}, \mathrm{Na}_{2} \mathrm{HPO}_{4} \cdot 12 \mathrm{H}_{2} \mathrm{O}$ $11 \mathrm{~g} / \mathrm{L}, \mathrm{NH}_{4} \mathrm{Cl} 16 \mathrm{~g} / \mathrm{L}, \mathrm{MgSO}_{4} \cdot 7 \mathrm{H}_{2} \mathrm{O} 1.4 \mathrm{~g} / \mathrm{L}$, and $1 \mathrm{~mL}$ of trace element solution, prepared as was described in Section 2.2.1. The medium was adjusted at $\mathrm{pH} 7.0$ before the addition of the oil (i.e., castor, Jatropha, or waste frying), at $20 \mathrm{~g} / \mathrm{L}$, and was supplemented with yeast extract $1 \mathrm{~g} / \mathrm{L}$. Jatropha and castor oils used in this work were from Colombia; the first one has higher proportion of oleic and linoleic acids, followed by palmitic and stearic acids; meanwhile this castor oil has high content of ricinoleic acid (Table 1).

Although the frying oil used in this work was not characterized, it is known that this kind of oil is rich in free fatty acids (mono- and diacylglycerol), total polar material (oxidized monomeric and dimeric and oligomeric triglycerides), and compounds such as aldehydes and ketones and polymerized triglycerides (dimeric and polymeric triglycerides with ring structure) [33].
2.2.3. Culture Media with Commercial Residual Glycerol and Glycerol as Carbon Sources. Two samples of glycerol as carbon sources were employed, glycerol GR (99.5\% v/v) and glycerol produced in the biodiesel industry $(81.6 \% \mathrm{v} / \mathrm{v})$. The culture contains glycerol GR (or the residual one (GRSB)) $10 \mathrm{~g} / \mathrm{L},\left(\mathrm{NH}_{4}\right)_{2} \mathrm{SO}_{4} 1 \mathrm{~g} / \mathrm{L}, \mathrm{KH}_{2} \mathrm{PO}_{4} 15 \mathrm{~g} / \mathrm{L}, \mathrm{Na}_{2} \mathrm{HPO}_{4} \cdot 12 \mathrm{H}_{2} \mathrm{O}$ $9 \mathrm{~g} / \mathrm{L}, \mathrm{MgSO}_{4} \cdot 7 \mathrm{H}_{2} \mathrm{O} 0.2 \mathrm{~g} / \mathrm{L}$, and $1 \mathrm{~mL}$ of trace element solution (for further information see Section 2.2.1). Similarly, the medium was supplemented with yeast extract $1 \mathrm{~g} / \mathrm{L}$ and adjusted at $\mathrm{pH}$ 7.0. According to Cavalheiro et al. [3], the carbon source was autoclaved separately before being added to the medium.

2.3. Terms of Microbial Growth. The bacterial growth was evaluated employing different substrates as carbon source, in a shaker Innova $^{\mathrm{Tm}} 4400$. In all cases $250 \mathrm{~mL}$ Erlenmeyer flasks were employed, with a working volume of $50 \mathrm{~mL}$, which was considered $10 \% \mathrm{v} / \mathrm{v}$ inoculum for.

2.3.1. Fermentations with Whey as a Carbon Source. All the strains tested were incubated at $30^{\circ} \mathrm{C}$ and $150 \mathrm{rpm} \mathrm{[23].} \mathrm{The}$ selection of the "more promising" bacteria-substrate system was according to dry biomass and the presence of PHA, produced under the same operating conditions $\left(30^{\circ} \mathrm{C}, \mathrm{pH} 7.0\right.$, and $150 \mathrm{rpm})$. The bacterial growth was monitored at different times (i.e., 0, 24, 36, 48, and $72 \mathrm{~h}$ ) by triplicate. Sampling points were selected according to previous evaluation of these systems [27, 34-36].

The chemical identification of PHA extraction biomass samples was carried out by GC/MS obtained for each strain.

2.3.2. Fermentations with Oils (Jatropha, Castor, and Frying) and Glycerol (GRG) as Carbon Sources. To choose the best bacteria-substrate system, a $4 \times 3$ factorial experimental design was developed; four factors (four carbon sources: castor, Jatropha, waste frying, and GRG) and 3 levels (3 microorganisms: B. megaterium, Bacillus sp., and L. lactis), with series of three replicates, keep the reaction time $(48 \mathrm{~h})$, temperature $\left(30^{\circ} \mathrm{C}\right), \mathrm{pH} 7.0$, stirring speed $(200 \mathrm{rpm})$, substrate concentration $(20 \mathrm{~g} / \mathrm{L})$, and volume of culture medium $(50 \mathrm{~mL})$ constant. The response variables were the amount of biomass $(\mathrm{g} / \mathrm{L})$ and PHA accumulation $(\mathrm{g} / \mathrm{L})$.

The chemical identification of the compounds in the samples obtained was carried out by GC/MS for each strain; likewise the biomass produced in fermentation processes was estimated. However, only those extracts displaying greater weights were subjected to analysis by GC/MS.

2.3.3. Fermentations with Residual Glycerol (RGSB) as a Carbon Source. GRSB assays were performed following the protocol described for GRG, but with a fermentation time of $72 \mathrm{~h}$, taking samples (in triplicate) for determination of biomass at $0,8,12,24,36$, and $72 \mathrm{~h}$, respectively.

2.4. Operational Conditions for the Production of PHA in Bacteria-Substrate System. To establish, on a laboratory scale, the best operating conditions for bacteria-substrate system, a factorial experimental design was performed using response surface analysis with series of three repetitions. The system 


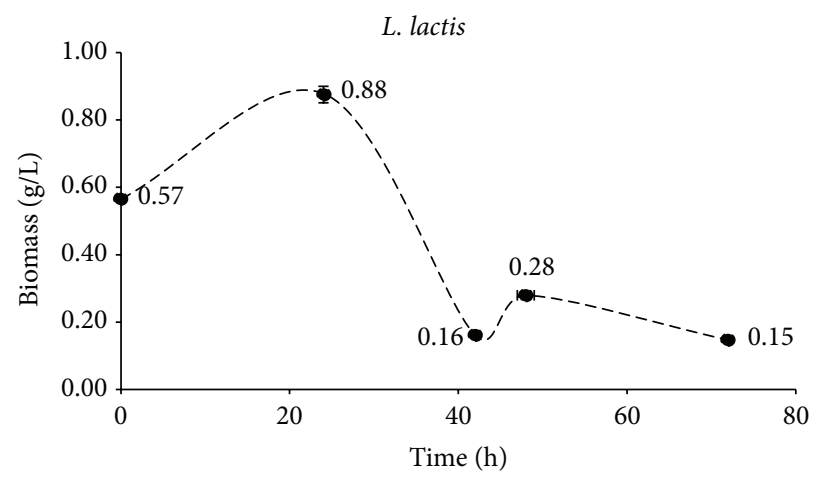

FIGURE 2: Growth of L. lactis employing whey as carbon source.

TABLE 2: Levels for each factor evaluated in PHA production.

\begin{tabular}{lccc}
\hline Level & & \multicolumn{2}{c}{ Factors } \\
& $T\left({ }^{\circ} \mathrm{C}\right)$ & $\mathrm{pH}$ & Substrate concentration $(\mathrm{g} / \mathrm{L})$ \\
\hline 1 & 25 & 5 & 8 \\
2 & 30 & 6 & 10 \\
3 & 35 & 7 & 15 \\
4 & - & 8 & 20 \\
5 & - & 9 & 22 \\
\hline
\end{tabular}

response variables were dry biomass production per unit volume, PHA concentration per unit volume, and yield $\left(Y_{p / s}\right)$. The constants were reaction time $48 \mathrm{~h}$, the agitation $200 \mathrm{rpm}$, and the volume of the culture medium $50 \mathrm{~mL}$.

Each response variable was studied under the proposed experimental design described in Table 2.

2.5. Analysis Methodologies. The selection of the best bacteria-substrate system was performed by the determination of microbial growth (dry biomass) and chemical parameters (PHA concentration).

2.5.1. Determination of Dry Biomass. The culture media were centrifuged at $8000 \mathrm{rpm}$ and $20^{\circ} \mathrm{C}, 5 \mathrm{~min}$ in a JOUAN MR22 Refrigerated centrifuge. The pellet was resuspended in Tris$\mathrm{HCl}$ buffer $\mathrm{pH} 7.0$ and frozen at $-70^{\circ} \mathrm{C}$ for subsequent lyophilization $\left(-50^{\circ} \mathrm{C}\right.$ and $\left.0.05 \mathrm{mBar}\right)$. The final powder was weighed with the aim to determine biomass. Media with oil were centrifuged with $n$-hexane $\left(8000 \mathrm{rpm}, 20^{\circ} \mathrm{C}, 5 \mathrm{~min}\right)$ to separate the biomass from oleaginous medium.

2.5.2. Extraction and Chemical Characterization by GC/MS of PHA. PHAs were extracted from the bacterial biomass using dispersions of chloroform $(99 \% \mathrm{v} / \mathrm{v})$ and sodium hypochlorite $(5 \% \mathrm{w} / \mathrm{v})$ [37]. $1 \mathrm{~mL}$ of each reagent per $20 \mathrm{mg}$ of dry biomass was added. The samples were shaken at $30^{\circ} \mathrm{C}$ and $200 \mathrm{rpm}$ for $1 \mathrm{~h}$ and centrifuged $(5 \mathrm{~min}, 8000 \mathrm{rpm}$ at room temperature) to separate the organic phase, enriched with PHA. Thereafter methanol (95\% v/v) was added dropwise to the organic extract until precipitation of PHA. The samples were kept at $4^{\circ} \mathrm{C}$, after $12 \mathrm{~h}$, and then the supernatant and the pellet were washed several times with methanol. Finally the polymer was subjected to drying at $60^{\circ} \mathrm{C}$ and was weighed.

Biopolymer characterization was performed at the Laboratory of Chromatography of the University Industrial of Santander, by gas chromatography with mass selective detector operated in the mode Selective Ion Monitoring (GCMS/SIM). The quantification was carried out by Standard ISO 5509, 2000, which requires derivatization to the corresponding methyl esters biopolymer. The column employed for analysis was DB-WAX $(60 \mathrm{~m} \times 0.25 \mathrm{~mm} \times 0.25 \mu \mathrm{mi})$. The injection was performed in splitless mode (Inyection volume $=1 \mu \mathrm{L})$. PHB $(19.6 \mathrm{~g})$ was employed as reference standard and benzoic acid as internal standard.

\section{Results and Discussion}

3.1. Selecting the Bacteria-Substrate System. The selection of the best bacteria-substrate system was made based on dry biomass and the amount of PHA produced in each of the fermentations broths.

3.1.1. Evaluation of Bacteria-Whey System. The evaluation of the native strains in media containing whey triggers in the maximum biomass production at 24,48 , and $36 \mathrm{~h}$, for L. lactis, Bacillus sp., and B. megaterium, respectively.

As shown in Figure 2 the major biomass production in the L. lactis-whey system occurred at $24 \mathrm{~h}$, with values of $0.88 \pm$ $0.04 \mathrm{~g} / \mathrm{L}$.

The microorganism displayed an exponential growth tendency between 0 and $24 \mathrm{~h}$.

In the case of Bacillus sp.-whey system, the highest biomass value $(0.22 \pm 0.02 \mathrm{~g} / \mathrm{L})$ occurred at $48 \mathrm{~h}$ and represented only a quarter of the biomass obtained with $L$. lactis in just $24 \mathrm{~h}$ (Figure 3).

The low amount of biomass generated by this system could be related to low capacity of Bacillus sp. to absorb the whey. In this system, the step of adapting the microorganism into the medium was slower than L. lactis on the same substrate and under the same conditions, and their growth phase began after $30 \mathrm{~h}$, followed by a decrease between 48 and $72 \mathrm{~h}$.

Finally, the system with B. megaterium-whey is illustrated in Figure 4. In this case, the tendency of microbial exponential growth is observed from time zero with a maximum 


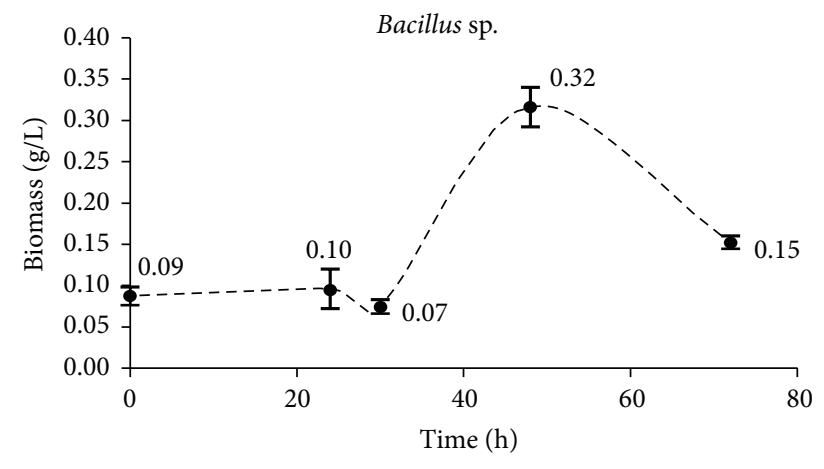

FIGURE 3: Growth of Bacillus sp. employing whey as carbon source.

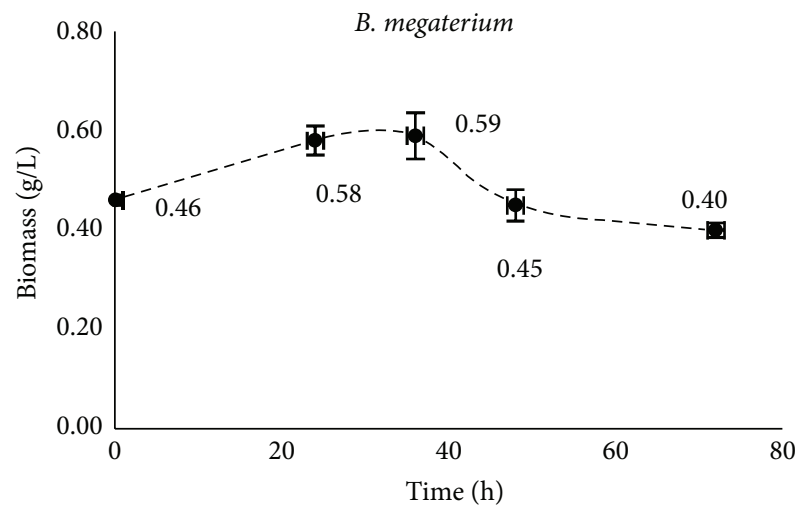

FIGURE 4: Growth of B. megaterium employing whey as carbon source.

biomass $(0.59 \pm 0.06 \mathrm{~g} / \mathrm{L})$ at $36 \mathrm{~h}$, whereas between 36 and $72 \mathrm{~h}$ a phase decay is seen, reaching biomass values $0.40 \pm 0.05 \mathrm{~g} / \mathrm{L}$ at $72 \mathrm{~h}$.

In contrast, the highest concentration of biopolymer was detected in the $B$. megaterium-whey system. Despite the greater biomass concentration $(0.88 \pm 0.04 \mathrm{~g} / \mathrm{L})$ in the system containing L. lactis, the biopolymer production by this microorganism was really low (detected at trace concentrations). This behavior could be related with the growth of $L$. lactis which is based on the metabolic degradation of lactose, substrate barely assimilated by microorganisms which lack lactase enzyme responsible for its degradation.

According to the results, the combination B. megateriumwhey was the best system. However, biomass values obtained in the all systems evaluated are far from the values of biomass $(3.1 \mathrm{~g} / \mathrm{L}, 36 \mathrm{~h})$ obtained with $B$. megaterium in a broth enriched with glucose and operated under the same conditions (i.e., $30^{\circ} \mathrm{C}, \mathrm{pH} 7.0$, substrate concentration $20 \mathrm{~g} / \mathrm{L}$, and $150 \mathrm{rpm}$ ) [23] and obtained by Obruca et al. [34] in B. megaterium-cheese whey system $(2.82 \mathrm{~g} / \mathrm{L}, 30 \mathrm{~h})$ (with optimized carbon source).

The whey can be reported as carbon source in the production of biopolymers from $B$. megaterium [31,33], although in this case it did not display good performance, eventually caused by contamination with other byproducts of the processed cheese that develops in the dairy plant which was sampled (the variations in the composition of whey cheese

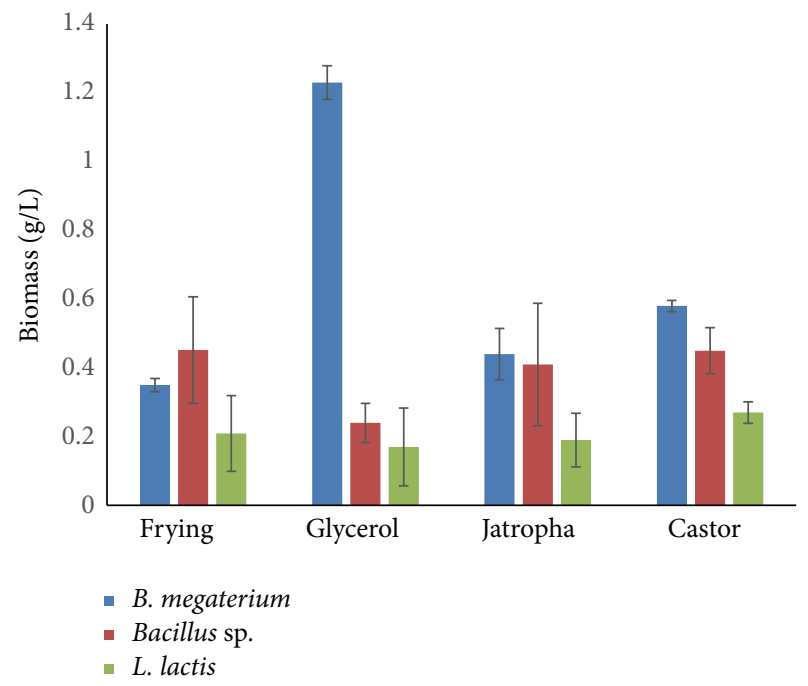

FIGURE 5: Dry biomass obtained in different systems (microorganism substrate).

day by day) such as precipitated proteins, which can act as inhibitors affecting the fermentation process.

It is noteworthy to mention that the aim of this study is to find inexpensive carbon sources to overcome the performance obtained with other substrates to get PHA such as glucose, which is employed at industrial level. Thus, further studies are required to improve the performance with $B$. megaterium, as an alternative to produce PHA.

3.1.2. Evaluation with Bacteria-Oily Substrates and BacteriaGlycerol Systems. The factorial arrangement established allowed the evaluation of the performance of the strains in media supplemented with oils (Jatropha, castor, and waste frying) and commercial glycerol. These tests allowed fast determination of the best bacteria-substrates combination, (i.e., production of biomass and PHA). Figure 5 illustrated comparatively biomass values obtained for each system. The best response was presented with the system $B$. megaterium glycerol, followed by B. megaterium-castor oil, Bacillus sp.waste frying oil, and Bacillus sp.-castor oil.

PHA production was examined in the B. megateriumglycerol systems, which showed the highest biomass production $(1.23 \pm 0.05 \mathrm{~g} / \mathrm{L})$, and $B$. megaterium-waste frying oil, which displayed lower bacterial growth $(0.35 \pm 0.02 \mathrm{~g} / \mathrm{L})$, but the carbon source is the cheaper of those tested in the present study. In B. megaterium-castor oil and Bacillus sp.-castor oil systems, there were bacterial growth and small amounts of polymer within their dry biomass extracts $(<10 \mathrm{mg})$; thus, they were not subjected to GC/MS, since microbial growth is low and castor oil is heavily used in industries energy (e.g., the production of biodiesel) and in factories (e.g., production of paints); therefore the process for producing PHA should be better to those cases in order to compete with other industrial processes. Finally in systems with Jatropha oil, precipitation of the polymer was no visible.

In Figure 6, the spectrum (obtained by GC/MS) of the methyl ester derivative of commercial 3-hydroxybutyric acid 


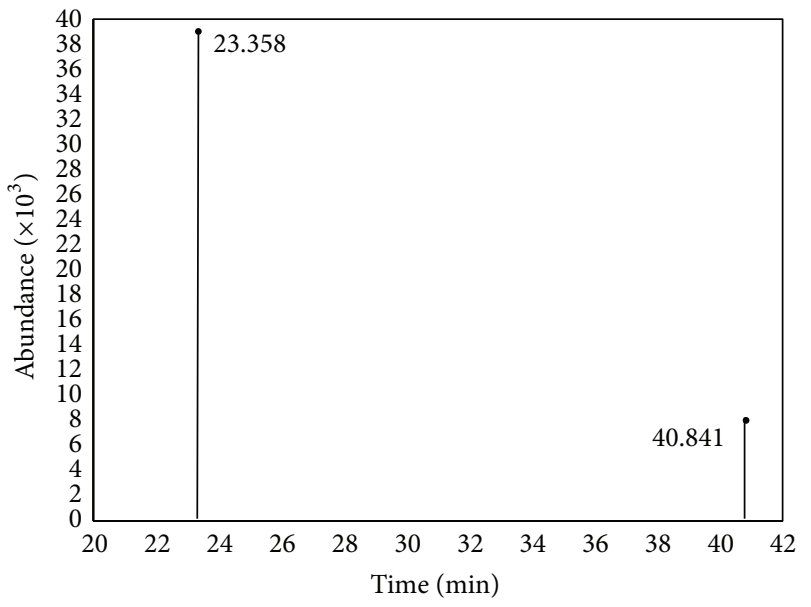

(a)

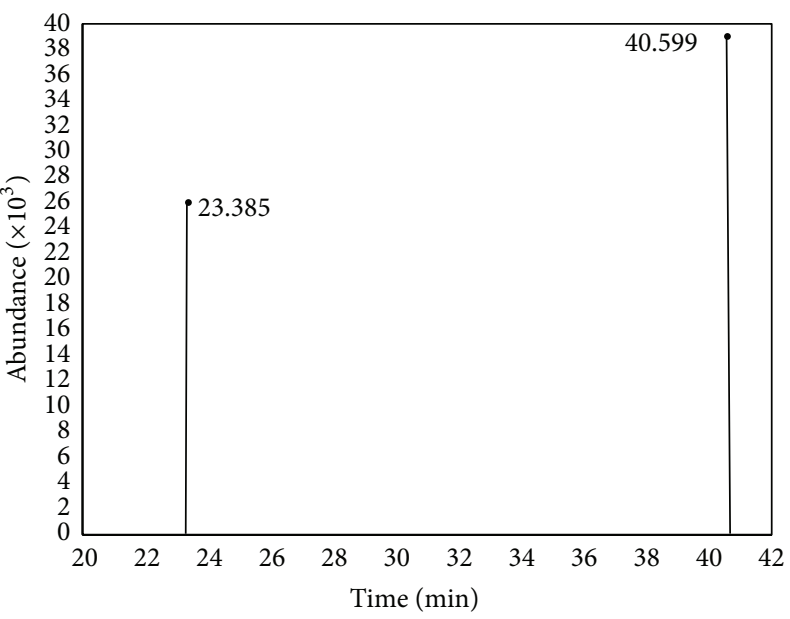

(b)

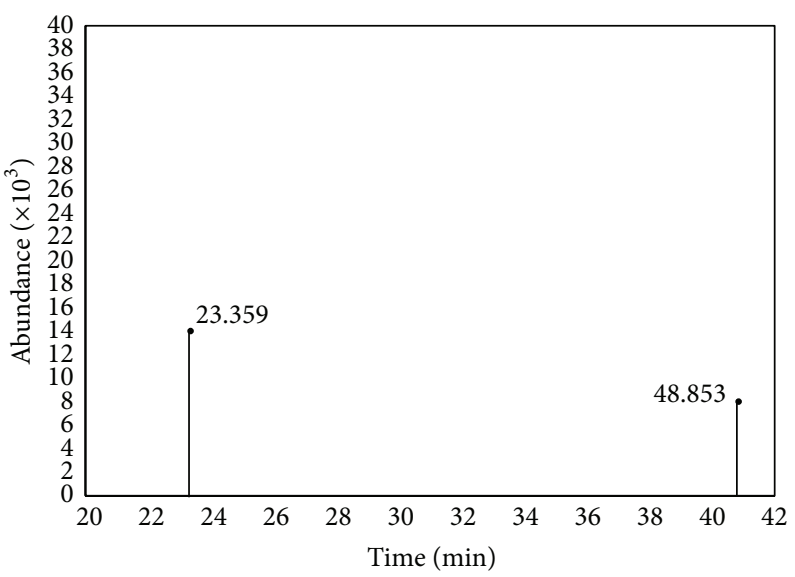

(c)

Figure 6: Mass spectrum (GC/MS) of the methyl ester derivative of (a) commercial 3-hydroxybutyric acid (PHB); (b) polymeric extract obtained with B. megaterium glycerol; and (c) the extract obtained with B. megaterium waste frying oil.

(PHB) is represented and the extract obtained in the system with B. megaterium-glycerol and B. megaterium-waste frying oil. The signal at $23.358 \mathrm{~min}$ corresponding to methylester methylether 3-hydroxybutyric acid (reference compound for quantification) and to the peak at $40.841 \mathrm{~min}$ is the internal standard (i.e., benzoic acid ester).

The best result obtained in the present study was B. megaterium-glycerol. In this system the biomass concentration at $48 \mathrm{~h}$ was $1.23 \pm 0.05 \mathrm{~g} / \mathrm{L}$. This system was selected as the best bacteria-substrate system for the production of PHB in this study. However, it is important to mention that the presence of PHB in the system with waste frying oil is remarkable, but further improvements should be developed in additional studies.

Accordingly, and with the aim of reducing costs in the production of $\mathrm{PHB}$, the following tests were made with the residual glycerol under the same operating conditions (i.e., substrate concentration, temperature, $\mathrm{pH}$, and agitation) employed with the reagent grade glycerol. Thus, the quantification and optimization of the operating parameters with residual glycerol was established.
In these experiments, the fermentation time was reduced from $72 \mathrm{~h}$, applied to systems with whey to $48 \mathrm{~h}$, based on existing literature concerning the production of PHA in oil and glycerol matrices, reporting times less than or equal to $48 \mathrm{~h}$. Thus, for example, Tian et al. [25], using Pseudomonas mendocina 0806 on substrates such as myristic and oleic acids characteristic oils tested in this research, found higher biomass accumulation and production of PHA at $48 \mathrm{~h} ; \mathrm{Ng}$ et al. [26] reported the same time for two variables, employing Cupriavidus necator H16 and Jatropha oil. Meanwhile, LópezCuellar et al. [38] reported increased production of PHB and biomass, after $40 \mathrm{~h}$ for Wisteria eutropha strain in canola oil; and Naranjo et al. [21] reported increased production of $\mathrm{PHB}$, at $45 \mathrm{~h}$, using a strain of B. megaterium and glycerol.

3.1.3. B. megaterium Residual Glycerol (RGSB) System. Glucose is the ultimate substrate, used in the PHA production at industrial level [2], which was considered as reference in this process. Data were obtained in our laboratory under the same operating conditions and are represented in Figure 7. 


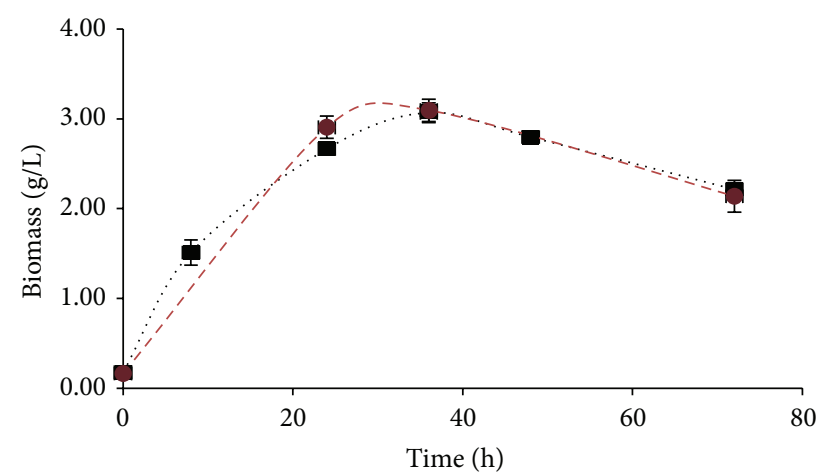

-.. Residual glycerol

- - Glucose

FIGURE 7: Growth curves of B. megaterium with residual glycerol and glucose.

B. megaterium displays a similar tendency of microbial growth in systems, reaching maximum values of $3.07 \pm$ $0.11 \mathrm{~g} / \mathrm{L}$ of biomass, in the medium with RGSB, and $3.096 \pm$ $0.124 \mathrm{~g} / \mathrm{L}$, in the medium supplemented with glucose [23]. The enzymatic assembly allows the fast absorption of the substrates. Glycerol is a sugar alcohol that can be incorporated in the metabolic pathway of carbohydrates for the synthesis of PHA. Similarly, the bacterium contains enzymes able to degrade fatty acids in broths supplemented with oils.

Comparing the biomass obtained with GRG (1.23 \pm $0.05 \mathrm{~g} / \mathrm{L} ;)$ at $48 \mathrm{~h}$ and that obtained with GRSB $(2.80 \pm$ $0.11 \mathrm{~g} / \mathrm{L}$;) under the same operational conditions the behavior in the first one was better. The microorganism exploits the different carbon sources present in the substrate, because possibly it is not completely pure. This behavior is according to Cavalheiro and coworkers [3], in systems with C. necatorpure glycerol (yield $Y_{x / s}=0.37 \mathrm{~g}_{\mathrm{DW}} / \mathrm{g}_{\mathrm{gly}}$ ) and $C$. necatorresidual glycerol (yield $Y_{x / s}=0.45 \mathrm{~g}_{\mathrm{DW}} / \mathrm{g}_{\text {rgly }}$ ).

The findings of this assessment and the ability of $B$. megaterium to accumulate PHA in GRG and its potential to produce PHA from RGSB were established, Thus, RGSB is very attractive for the production of biopolymers. In this sense, we preceded to optimize conditions for the production of PHB from RGSB.

\subsection{Response Surface Designs}

3.2.1. Dry Biomass Production and PHA. The higher biomass production obtained with this system was $4.62 \mathrm{~g} / \mathrm{L}$, at $25^{\circ} \mathrm{C}$ (RGSB, $20 \mathrm{~g} / \mathrm{L}$, and $\mathrm{pH}, 8.0$ ). In contrast, higher amount of PHA was $3.06 \mathrm{~g} / \mathrm{L}$ at $25^{\circ} \mathrm{C}$ RGSB, $15 \mathrm{~g} / \mathrm{L}$, and $\mathrm{pH} 7.0$, with a percentage of PHA of the dry biomass of $86.69 \%$ and yield $Y_{p / s} 204.1 \mathrm{mg} / \mathrm{g}$.

Rising the temperature till $30^{\circ} \mathrm{C}$ triggers higher biomass production $(3.69 \mathrm{~g} / \mathrm{L})$ at $\mathrm{RGSB} 15 \mathrm{~g} / \mathrm{L}$ and $\mathrm{pH} 9.0$, and the PHA production was $0.81 \mathrm{~g} / \mathrm{L}$ at RGSB $15 \mathrm{~g} / \mathrm{L}$ and $\mathrm{pH} 5.0$, with a percentage of PHA from the dry biomass equivalent to $96.89 \%$ and yield $Y_{p / s} 54.0 \mathrm{mg} / \mathrm{g}$.

With the increase of the temperature of the system to $35^{\circ} \mathrm{C}$, the production of biomass was increased $(4.46 \mathrm{~g} / \mathrm{L})$ employing RGSB, $15 \mathrm{~g} / \mathrm{L}$, and $\mathrm{pH}$ 5.0. Meanwhile most PHA production $(0.74 \mathrm{~g} / \mathrm{L})$ occurred while employing RGSB, $20 \mathrm{~g} / \mathrm{L}$, and $\mathrm{pH} 6.0$ with a percentage of PHA of the dry biomass of $45.04 \%$ and yield $Y_{p / s} 36.8 \mathrm{mg} / \mathrm{g}$.

Thus, higher temperatures affect negatively the bacterial growth and the accumulation of PHA.

3.2.2. Response Surfaces for Biomass Production. In Figures $8-10$, the system behavior ( $B$. megaterium-RGSB) relative to the biomass produced under the conditions evaluated according to the substrate concentration (residual glycerol) and the $\mathrm{pH}$ is illustrated. Moreover, statistical models adjusted to the system estimated values that maximize biomass production (optimal) of each of the factors studied, for each temperature evaluated $\left(25^{\circ} \mathrm{C}, 30^{\circ} \mathrm{C}\right.$, and $\left.35^{\circ} \mathrm{C}\right)$.

In Figure 8, constructed for biomass at $25^{\circ} \mathrm{C}$, a curvature surface is observed with a possible maximum concentration of biomass for $22 \mathrm{~g} / \mathrm{L}$ and $\mathrm{pH}$ 9.0. Moreover, in conditions close to $8 \mathrm{~g} / \mathrm{L}$ and $\mathrm{pH} 7.0$, the region of lower concentration is observed for biomass. In the intermediate region up "apparent" biomass at $\mathrm{pH}$ values close to $15 \mathrm{~g} / \mathrm{L}, \mathrm{pH} 7.0$ is observed. The contour plot (Figure 8(b)) displays the tendency of the system to the maximum biomass concentration points.

In Figure 9(a), the surface for the biomass at $30^{\circ} \mathrm{C}$ is displayed; a curvature occurs towards a possible biomass concentration $(8 \mathrm{~g} / \mathrm{L}, \mathrm{pH} 9.0)$. At $8 \mathrm{~g} / \mathrm{L}$ and $\mathrm{pH} 5.0$ on the surface the lower concentration of biomass for the system was observed. The contour plot (Figure 9(b)) displays the tendency of the system to the maximum biomass concentration points.

In Figure 10(a), the surface for the biomass at $35^{\circ} \mathrm{C}$ is displayed, in which the tendency of the system to its maximum value is displayed in the selected region to system conditions around (15 g/L illustrated, $\mathrm{pH} 9.0)$. The contour plot (Figure 10(b)) shows the tendency of the system to the maximum biomass concentration.

3.2.3. Response Surfaces for PHA Production. The surfaces obtained (Figures 11-13) display regions evaluated and behavior B. megaterium residual glycerol system, regarding PHA production, under the proposed conditions of operation.

In Figure 11(a), the concentration of PHA at $25^{\circ} \mathrm{C}$ displays the maximum concentration of PHA observed in the region of selected study values close to $15 \mathrm{~g} / \mathrm{L}, \mathrm{pH}$ 7.0. Moreover for values of $8 \mathrm{~g} / \mathrm{L}, \mathrm{pH}$ 9.0, the lowest concentration for PHA is observed. The contour plot (Figure 11) displays the region where the peak concentration for PHA, the conditions of $\mathrm{pH}$, and substrate concentration are selected in the experimental design.

The concentration of PHA at $30^{\circ} \mathrm{C}$ (Figure $12(\mathrm{a})$ ) displays a region of the maximum possible concentration of PHA in the system presented $(15 \mathrm{~g} / \mathrm{L}, \mathrm{pH} 5.0)$; for values of $8 \mathrm{~g} / \mathrm{L}, \mathrm{pH} 9.0$, the point is observed on the surface of lower concentration for PHA accumulation. The contour plot (Figure 12(b)) displays the tendency of the system to the maximum concentration PHA.

In Figure 13(a), the concentration of $\mathrm{PHA}$ at $35^{\circ} \mathrm{C}$ is illustrated. In this case, a saddle point occurs for values between $10 \mathrm{~g} / \mathrm{L}$ and $15 \mathrm{~g} / \mathrm{L}$ and $\mathrm{pH} 7.0$ and $\mathrm{pH}$ 8.0, with 


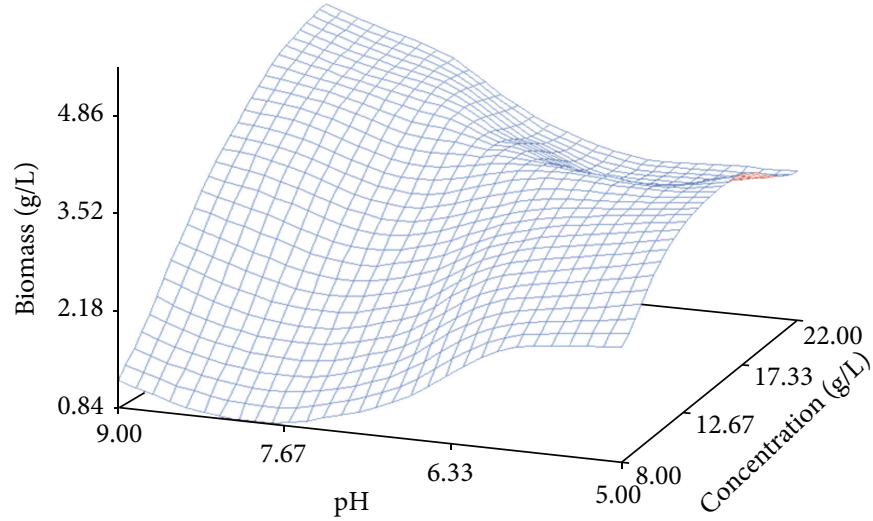

(a)

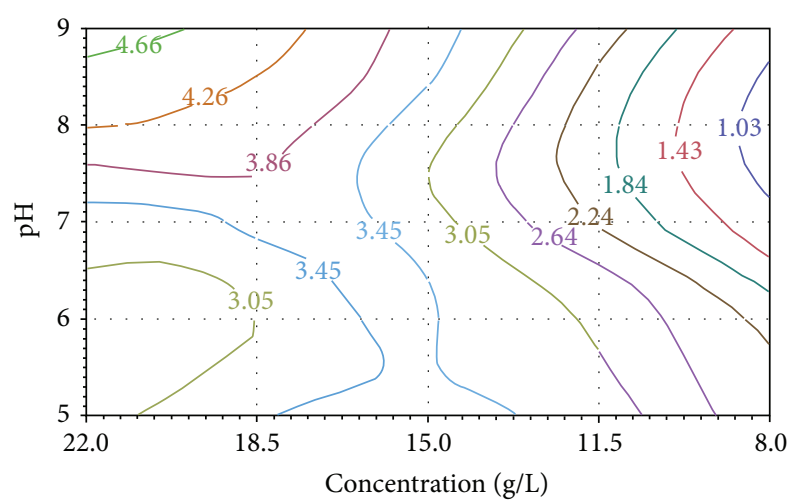

(b)

Figure 8: Biomass obtained in the B. megaterium residual glycerol system at $25^{\circ} \mathrm{C}$. (a) Response surface for biomass. (b) Contour diagram for biomass in function of $\mathrm{pH}$ and substrate concentration.

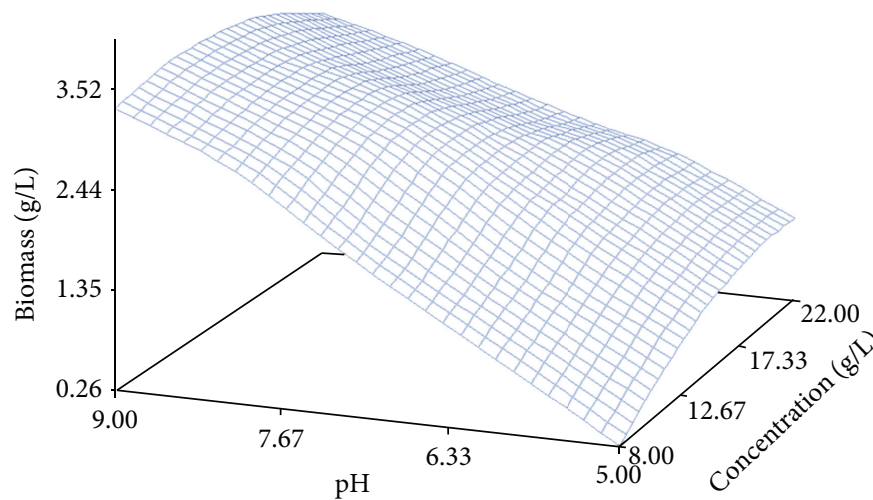

(a)

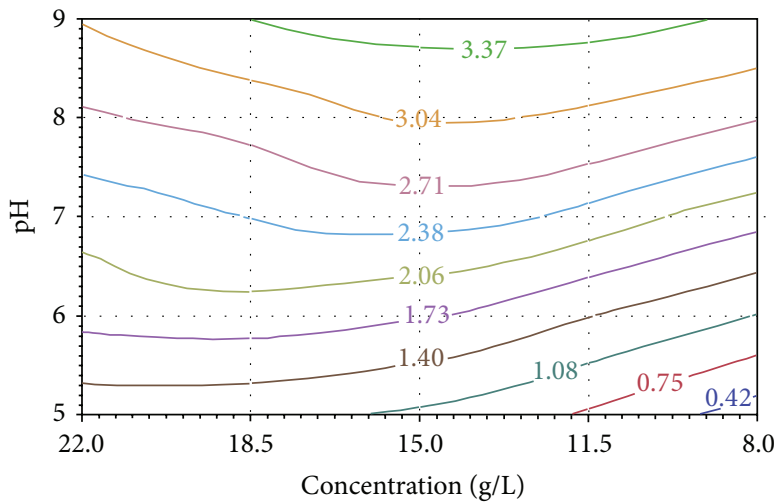

(b)

Figure 9: Biomass obtained in the B. megaterium residual glycerol system at $30^{\circ} \mathrm{C}$. (a) Response surface for biomass. (b) Contour diagram for biomass in function of $\mathrm{pH}$ and substrate concentration.

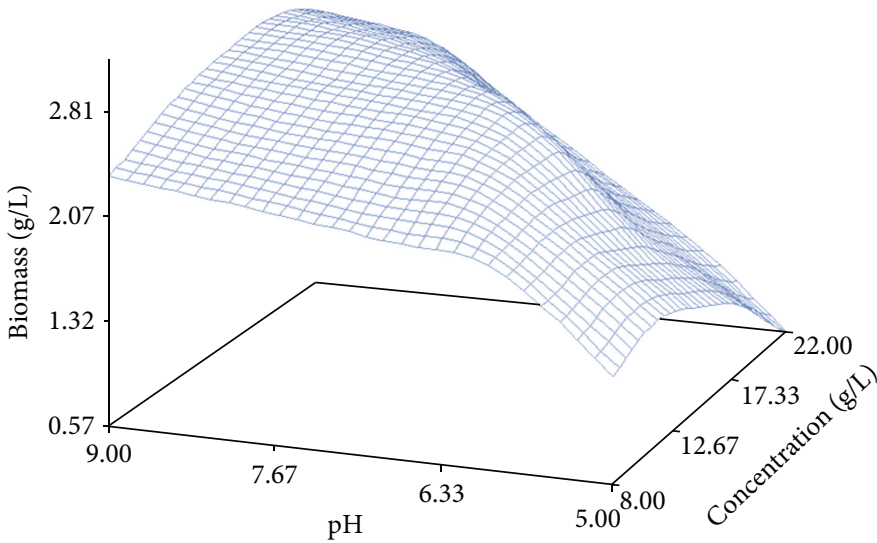

(a)

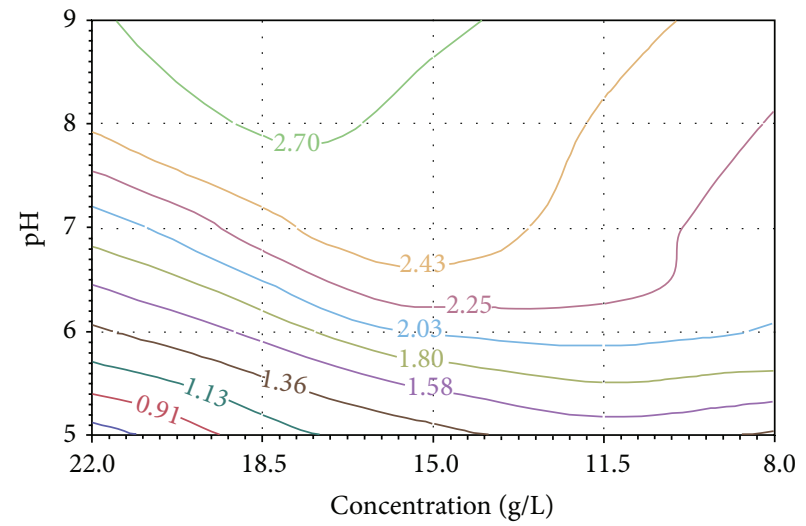

(b)

Figure 10: Biomass obtained in the B. megaterium residual glycerol system at $35^{\circ} \mathrm{C}$. (a) Response surface for biomass. (b) Contour diagram for biomass in function of $\mathrm{pH}$ and substrate concentration. 


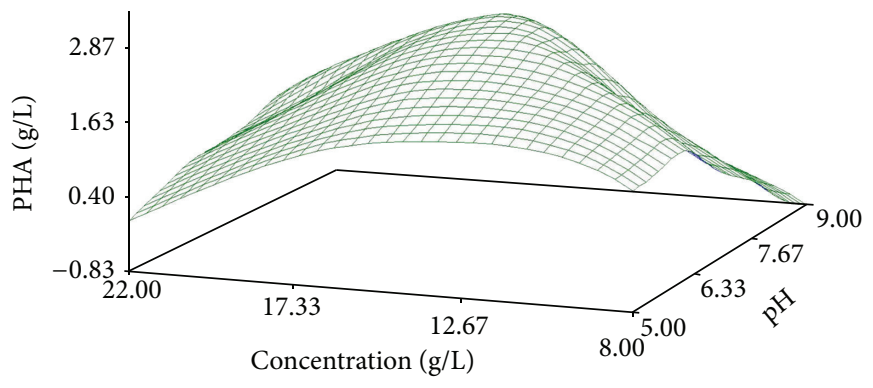

(a)

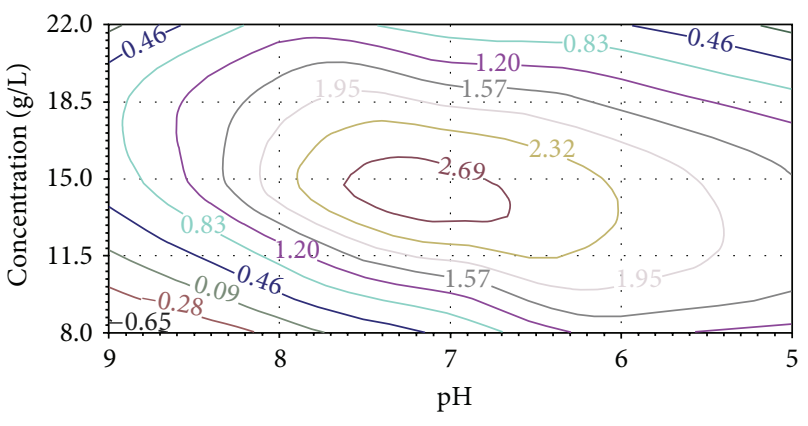

(b)

Figure 11: PHA production in B. megaterium residual glycerol system at $25^{\circ} \mathrm{C}$. (a) Response surface obtained for PHA accumulation. (b) Contour plot for PHA production in function of substrate concentration and $\mathrm{pH}$.

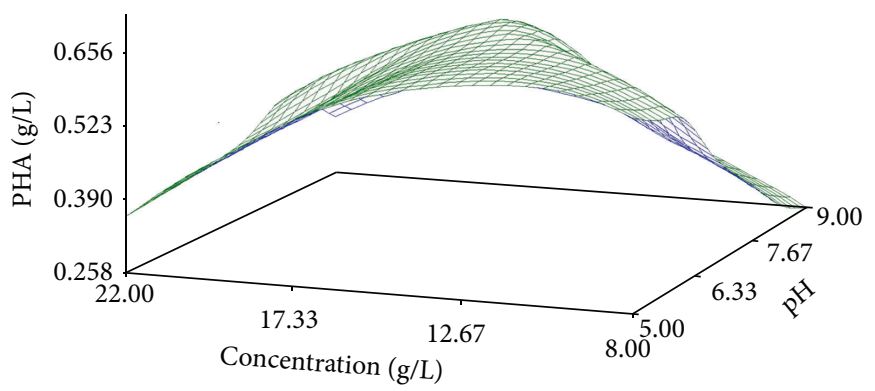

(a)

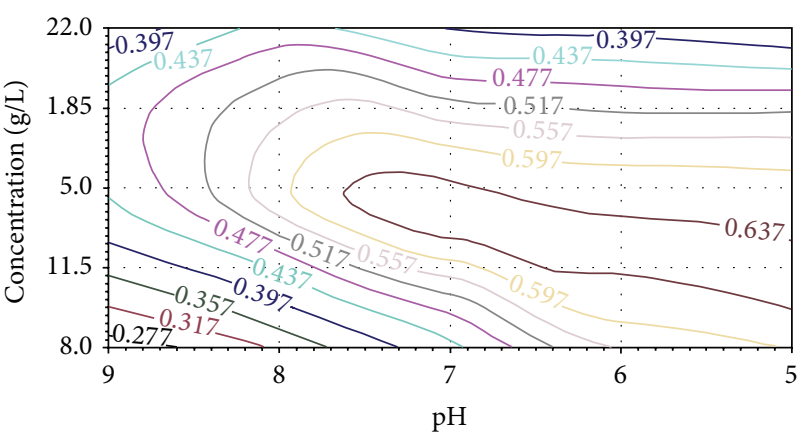

(b)

Figure 12: PHA production in B. megaterium residual glycerol system at $30^{\circ} \mathrm{C}$. (a) Response surface obtained for PHA accumulation. (b) Contour plot for PHA production in function of substrate concentration and $\mathrm{pH}$.

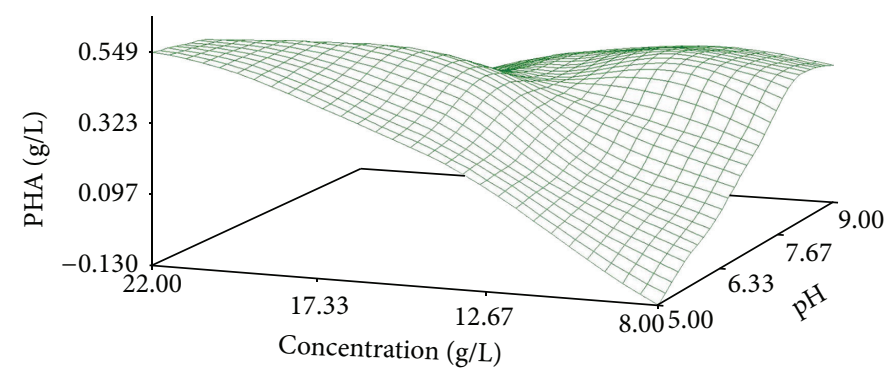

(a)

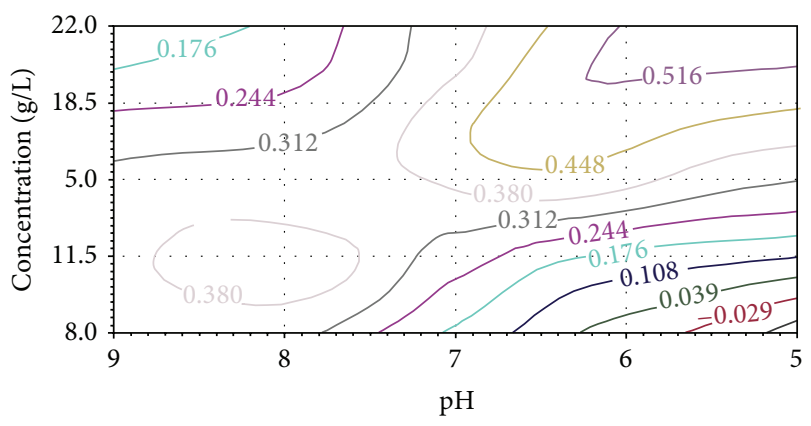

(b)

Figure 13: PHA production in B. megaterium residual glycerol system at $35^{\circ} \mathrm{C}$. (a) Response surface obtained for PHA accumulation. (b) Contour plot for PHA production in function of substrate concentration and $\mathrm{pH}$.

a maximum possible for values close to $22 \mathrm{~g} / \mathrm{L}$ and $\mathrm{pH} 9.0$. The contour diagram (Figure 13(b)) displays the tendency of the system to the maximum concentration of PHA.

3.2.4. Response Surface for Substrate Yield Global Product $Y_{p / s}$. Surfaces found (Figures 14-16) to yield PHA per unit substrate $\left(Y_{p / s}\right)$ show the regions of interest for the target system.

In Figure 14(a), yield $Y_{p / s}$ at $25^{\circ} \mathrm{C}$ is displayed and a curvature is observed to the maximum concentration possible
$Y_{p / s}$, close to $15 \mathrm{~g} / \mathrm{L}, \mathrm{pH}$ 7.0. The extreme conditions $(22 \mathrm{~g} / \mathrm{L}$, $\mathrm{pH}$ 5.0) and (8 g/L, pH 9.0) had the minimum system values for $Y_{p / s}$. The contour plot (Figure 14(b)) displays the tendency of the system to yield $Y_{p / s}$.

For yield $Y_{p / s}$ at $30^{\circ} \mathrm{C}$ (Figure 15(a)), it is clear that maximum performance is not in the study area proposed for optimization. However, it can be seen that for acid $\mathrm{pH}$ values and low substrate concentrations, the yield increases. The contour plot (Figure 15(b)) shows the tendency of the system to yield $Y_{p / s}$. 


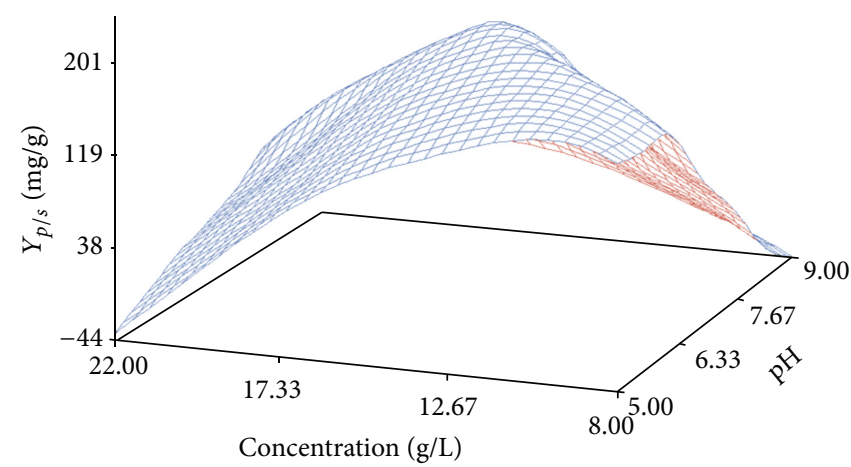

(a)

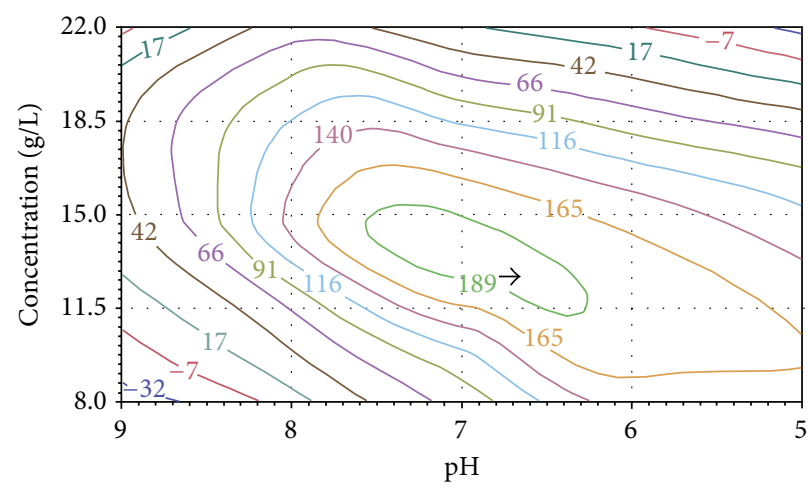

(b)

FiguRE 14: PHA yield per unit of substrate in B. megaterium residual glycerol system at $25^{\circ} \mathrm{C}$. (a) Response surface obtained for $Y_{p / s}$. (b) Contour plot for the surface obtained in function of substrate concentration and $\mathrm{pH}$ evaluated.

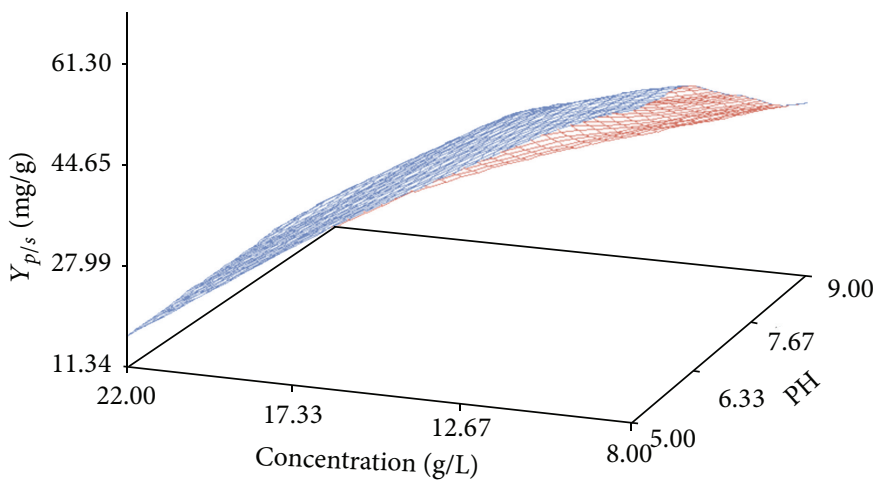

(a)

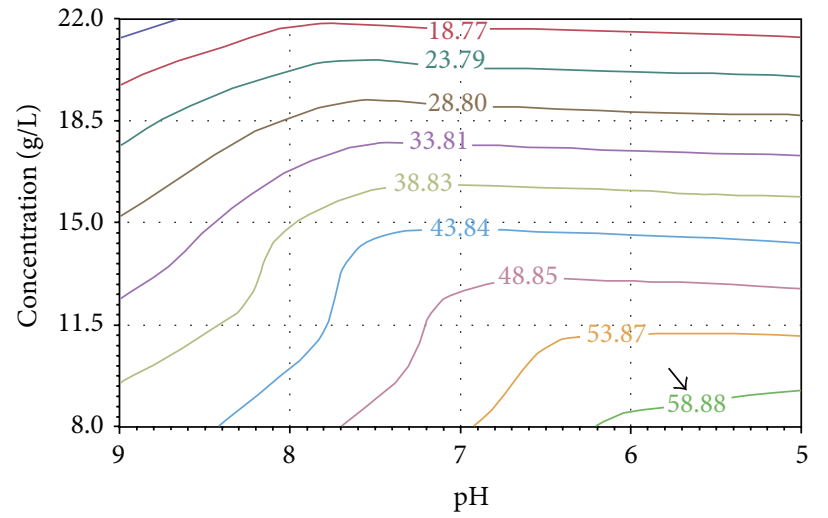

(b)

FiguRE 15: PHA yield per unit of substrate in B. megaterium residual glycerol system at $30^{\circ} \mathrm{C}$. (a) Response surface obtained for $Y_{p / s}$. (b) Contour plot for the surface obtained in function of substrate concentration and $\mathrm{pH}$ evaluated.

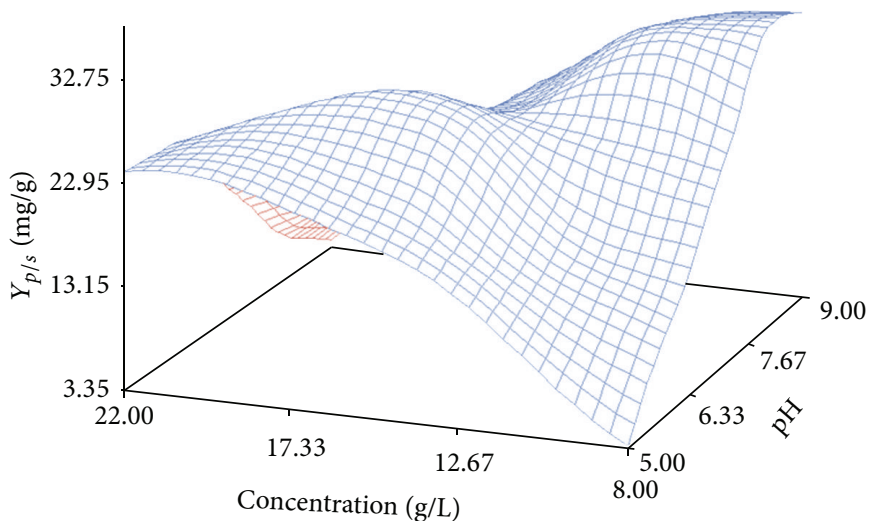

(a)

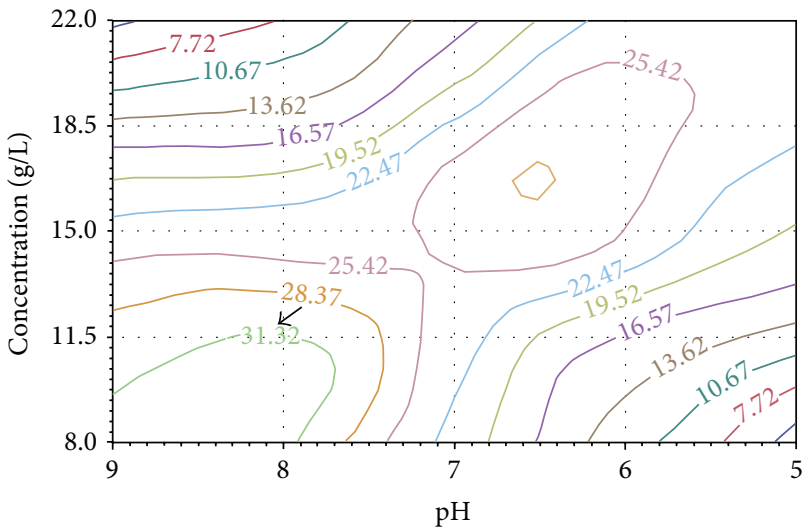

(b)

Figure 16: PHA yield per unit substrate in B. megaterium residual glycerol system at $35^{\circ} \mathrm{C}$. (a) Response surface obtained for $Y_{p / s}$. (b) Contour plot for the surface obtained in function of substrate concentration and $\mathrm{pH}$ evaluated. 
In Figure 16(a), yield $Y_{p / s}$ at $35^{\circ} \mathrm{C}$ is illustrated. The tendency of the system values is displayed to its maximum value close to $10 \mathrm{~g} / \mathrm{L}$ and $\mathrm{pH} 8.0$ values shown. The contour plot (Figure 16(b)) shows the tendency of the system to maximum yield $Y_{p / s}$.

\section{Conclusions}

All substrates tested (castor oil, frying oil, Jatropha oil, GRG, RGSB, and whey) were suitable for the growth of the strains B. megaterium, Bacillus sp., and L. lactis; however, the low biomass concentrations obtained for some systems are an obstacle for PHA production.

B. megaterium strain has the property of growing in sugar substrates, oily substrates, and glycerol; the latter has the advantage of producing $\mathrm{PHB}$ in amounts similar to those produced from sugar residues, under the operating conditions used in this experiment.

By cultivating native strain $B$. megaterium in liquid medium supplemented with GRG as a source of carbon, it is from a combined bacteria-substrate system very promising for the production of $\mathrm{PHB}$, which allows using RGSB to $81.6 \%$ $\mathrm{v} / \mathrm{v}$ to obtain $2.80 \mathrm{~g} / \mathrm{L} \mathrm{PHB}$, a yield of $Y_{p / s} 186.8 \mathrm{mg} / \mathrm{g}$ in a

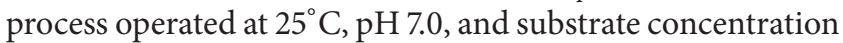
$15 \mathrm{~g} / \mathrm{L}$.

The optimal values for the system are given under operating conditions of RGSB $14.8 \mathrm{~g} / \mathrm{L}, \mathrm{pH} 6.7$, and $25^{\circ} \mathrm{C}$, with PHB production of $2.81 \mathrm{~g} / \mathrm{L}$ and product yield $Y_{p / s} 189.9 \mathrm{mg} / \mathrm{g}$.

The work area to optimize B. megaterium-RGSB system and obtain greater amounts of biopolymer (estimated in $\mathrm{g} / \mathrm{L}$ ) is at temperatures close to $25^{\circ} \mathrm{C}$, residual glycerol concentrations close to $15 \mathrm{~g} / \mathrm{L}$, and $\mathrm{pHs}$ close to neutrality.

The use of $B$. megaterium residual glycerol system to $\mathrm{PHB}$ production is a doubly green process; it would solve the problem of biodiesel industry associated with the generation of residual glycerol and it would generate an added value, contributing to reduce pollution by petroleum-based plastics.

\section{Conflict of Interests}

The authors declare that there is no conflict of interests regarding the publication of this paper.

\section{Acknowledgments}

The authors are pleased to acknowledge Dr. Mauricio Alejandro Marín Montoya and Dr. Blanca Fabiola Espejos Benavides for their support and collaboration in this investigation. This work was supported by Laboratorio de Venenos Naturales, Laboratorio de Análisis y Procesos Ambientales, Laboratorio de Biología Celular y Molecular, Laboratorio de Análisis Instrumental, Universidad Nacional de Colombia, Sede Medellín, El Laboratorio de Cromatografía de la Universidad Industrial de Santander, and Escuela de Ingenieros de Antioquia. Special thanks are due to Dr. Rodrigo Velasco Bucheli for his assistance.

\section{References}

[1] L. Castro Puig, "Los plásticos en el ámbito mundial," June 2011, https://airdplastico.wordpress.com/2011/06/02/los-plasticos-enel-ambito-mundial/.

[2] S. Chanprateep, "Current trends in biodegradable polyhydroxyalkanoates," Journal of Bioscience and Bioengineering, vol. 110, no. 6, pp. 621-632, 2010.

[3] J. M. B. T. Cavalheiro, M. C. M. D. de Almeida, C. Grandfils, and M. M. R. da Fonseca, "Poly(3-hydroxybutyrate) production by Cupriavidus necator using waste glycerol," Process Biochemistry, vol. 44, no. 5, pp. 509-515, 2009.

[4] Y.-M. Corre, S. Bruzaud, J.-L. Audic, and Y. Grohens, "Morphology and functional properties of commercial polyhydroxyalkanoates: a comprehensive and comparative study," Polymer Testing, vol. 31, no. 2, pp. 226-235, 2012.

[5] P. Suriyamongkol, R. Weselake, S. Narine, M. Moloney, and S. Shah, "Biotechnological approaches for the production of polyhydroxyalkanoates in microorganisms and plants-a review," Biotechnology Advances, vol. 25, no. 2, pp. 148-175, 2007.

[6] B. Laycock, P. Halley, S. Pratt, A. Werker, and P. Lant, "The chemomechanical properties of microbial polyhydroxyalkanoates," Progress in Polymer Science, vol. 39, no. 2, pp. 397-442, 2014.

[7] Y.-M. Wong, C. J. Brigham, C. Rha, A. J. Sinskey, and K. Sudesh, "Biosynthesis and characterization of polyhydroxyalkanoate containing high 3-hydroxyhexanoate monomer fraction from crude palm kernel oil by recombinant Cupriavidus necator," Bioresource Technology, vol. 121, pp. 320-327, 2012.

[8] J. A. Posada, J. M. Naranjo, J. A. López, J. C. Higuita, and C. A. Cardona, "Design and analysis of poly-3-hydroxybutyrate production processes from crude glycerol," Process Biochemistry, vol. 46, no. 1, pp. 310-317, 2011.

[9] E. Bugnicourt, P. Cinelli, A. Lazzeri, and V. Alvarez, "Polyhydroxyalkanoate (PHA): review of synthesis, characteristics, processing and potential applications in packaging," Express Polymer Letters, vol. 8, no. 11, pp. 791-808, 2014.

[10] D. E. Agnew and B. F. Pfleger, "Synthetic biology strategies for synthesizing polyhydroxyalkanoates from unrelated carbon sources," Chemical Engineering Science, vol. 103, pp. 58-67, 2013.

[11] D. M. Alonso, J. Q. Bond, and J. A. Dumesic, "Catalytic conversion of biomass to biofuels," Green Chemistry, vol. 12, no. 9, pp. 1493-1513, 2010.

[12] G. N. Lee and J. Na, "Future of microbial polyesters," Microbial Cell Factories, vol. 12, article 54, 2013.

[13] Z. Liu, Y. Wang, N. He et al., "Optimization of polyhydroxybutyrate (PHB) production by excess activated sludge and microbial community analysis," Journal of Hazardous Materials, vol. 185, no. 1, pp. 8-16, 2011.

[14] M. Villano, F. Valentino, A. Barbetta, L. Martino, M. Scandola, and M. Majone, "Polyhydroxyalkanoates production with mixed microbial cultures: from culture selection to polymer recovery in a high-rate continuous process," New Biotechnology, vol. 31, no. 4, pp. 289-296, 2014.

[15] Z. U. Salmiati, M. R. Salim, and G. Olsson, "Recovery of polyhydroxyalkanoates (PHAs) from mixed microbial cultures by simple digestion and saponification," in Proceedings of the $3 r d$ International Water Association (IWA)-ASPIRE, Conference and Exhibition, pp. 8-15, Taipei, Taiwan, October 2009.

[16] Y. Gao, X. Feng, M. Xian, Q. Wang, and G. Zhao, "Inducible cell lysis systems in microbial production of bio-based chemicals," 
Applied Microbiology and Biotechnology, vol. 97, no. 16, pp. 71217129, 2013.

[17] M. López-Abelairas, M. García-Torreiro, T. Lú-Chau, J. M. Lema, and A. Steinbüchel, "Comparison of several methods for the separation of poly(3-hydroxybutyrate) from Cupriavidus necator H16 cultures," Biochemical Engineering Journal, vol. 93, pp. 250-259, 2015.

[18] F. Rébeillé, S. Jabrin, R. Bligny et al., "Methionine catabolism in Arabidopsis cells is initiated by a $\gamma$-cleavage process and leads to S-methylcysteine and isoleucine syntheses," Proceedings of the National Academy of Sciences of the United States, vol. 103, no. 42, pp. 15687-15692, 2006.

[19] K. D. Snell, V. Singh, and S. M. Brumbley, "Production of novel biopolymers in plants: recent technological advances and future prospects," Current Opinion in Biotechnology, vol. 32, pp. 68-75, 2015.

[20] A. Narayanan and K. V. Ramana, "Polyhydroxybutyrate production in Bacillus mycoides DFC1 using response surface optimization for physico-chemical process parameters," 3 Biotech, vol. 2, no. 4, pp. 287-296, 2012.

[21] J. M. Naranjo, J. C. Higuita Vásquez, and C. A. Cardona, Producción de Polihidroxibutirato a Partir de Residuos Agroindustriales, Universidad Nacional de Colombia-Sede Manizales, 2010.

[22] A. D. Tripathi, S. K. Srivastava, and R. P. Singh, "Statistical optimization of physical process variables for bio-plastic (PHB) production by Alcaligenes sp.," Biomass and Bioenergy, vol. 55, pp. 243-250, 2013.

[23] A. Salazar, Parámetros Operacionales Óptimos Para La Producción de Bioplásticos a Partir de Fuentes Renovables Azucaradas, Universidad Nacional de Colombia-Sede Medellín, 2011.

[24] A. A. Pantazaki, C. P. Papaneophytou, A. G. Pritsa, M. Liakopoulou-Kyriakides, and D. A. Kyriakidis, "Production of polyhydroxyalkanoates from whey by Thermus thermophilus HB8," Process Biochemistry, vol. 44, no. 8, pp. 847-853, 2009.

[25] W. Tian, K. Hong, G.-Q. Chen, Q. Wu, R.-Q. Zhang, and W. Huang, "Production of polyesters consisting of medium chain length 3-hydroxyalkanoic acids by Pseudomonas mendocina 0806 from various carbon sources," Antonie van Leeuwenhoek, vol. 77, no. 1, pp. 31-36, 2000.

[26] K.-S. Ng, W.-Y. Ooi, L.-K. Goh, R. Shenbagarathai, and K. Sudesh, "Evaluation of jatropha oil to produce poly(3-hydroxybutyrate) by Cupriavidus necator H16," Polymer Degradation and Stability, vol. 95, no. 8, pp. 1365-1369, 2010.

[27] A. Nath, M. Dixit, A. Bandiya, S. Chavda, and A. J. Desai, "Enhanced PHB production and scale up studies using cheese whey in fed batch culture of Methylobacterium sp. ZP24," Bioresource Technology, vol. 99, no. 13, pp. 5749-5755, 2008.

[28] S. A. Sánchez Moreno, M. A. Marín Montoya, A. L. Mora Martínez, and M. del S Yepes, "Identificación de bacterias productoras de polihidroxialcanoatos (PHAs) en suelos contaminados con desechos de fique," Revista Colombiana de Biotecnología, vol. 14, no. 2, pp. 89-100, 2012.

[29] A. C. Cardona, A. Mora, and M. Marín, "Molecular identification of polyhydroxyalkanoate-producing bacteria isolated from dairy and sugarcane residues," Revista Facultad Nacional de Agronomía, vol. 66, no. 2, pp. 7129-7140, 2013.

[30] R. O. Montenegro and S. Magnitskiy, "Effect of nitrogen and potassium fertilization on the production and quality of oil in Jatropha curcas L. under the dry and warm climate conditions of
Colombia," Agronomia Colombiana, vol. 32, no. 2, pp. 255-265, 2014.

[31] I. Sánchez and K. Huertas, “Obtención y caracterización de biodiesel a partir de aceite de semillas de Ricinus communis. (Higuerilla) modificadas géneticamente y cultivadas en el Eje Cafetero," Tech. Rep., Universidad Tecnológica de Pereira, 2012.

[32] S. Cardona, R. González, A. Franco, F. Cardeño, and L. Ríos, "Production of monoglycerides from castor oil using crude and refined glycerin. Study of the main variables of the process," Vitae, Revista de la Facultad de Química Farmacéutica, vol. 17, no. 2, pp. 128-134, 2010.

[33] H. Sanli, M. Canakci, and E. Alptekin, "Characterization of waste frying oils obtained from different facilities," in Proceedings of the World Renewable Energy Congress, pp. 479-485, Linköping, Sweden, May 2011.

[34] S. Obruca, I. Marova, S. Melusova, and L. Mravcova, "Production of polyhydroxyalkanoates from cheese whey employing Bacillus megaterium CCM 2037," Annals of Microbiology, vol. 61, no. 4, pp. 947-953, 2011.

[35] S. C. Y. Lee, J. Il Choi, H. H. Wong et al., "Recent advances in polyhydroxyalkanoate production by bacterial fermentation: mini-review," Process Biochemistry, vol. 25, no. 2, pp. 137-146, 2007.

[36] S. G. V. A. O. Costa, F. Lépine, S. Milot, E. Déziel, M. Nitschke, and J. Contiero, "Cassava wastewater as a substrate for the simultaneous production of rhamnolipids and polyhydroxyalkanoates by Pseudomonas aeruginosa," Journal of Industrial Microbiology and Biotechnology, vol. 36, no. 8, pp. 1063-1072, 2009.

[37] N. Jacquel, C.-W. Lo, Y.-H. Wei, H.-S. Wu, and S. S. Wang, "Isolation and purification of bacterial poly(3-hydroxyalkanoates)," Biochemical Engineering Journal, vol. 39, no. 1, pp. 15-27, 2008.

[38] M. R. López-Cuellar, J. Alba-Flores, J. N. G. Rodríguez, and F. Pérez-Guevara, "Production of polyhydroxyalkanoates (PHAs) with canola oil as carbon source," International Journal of Biological Macromolecules, vol. 48, no. 1, pp. 74-80, 2011. 

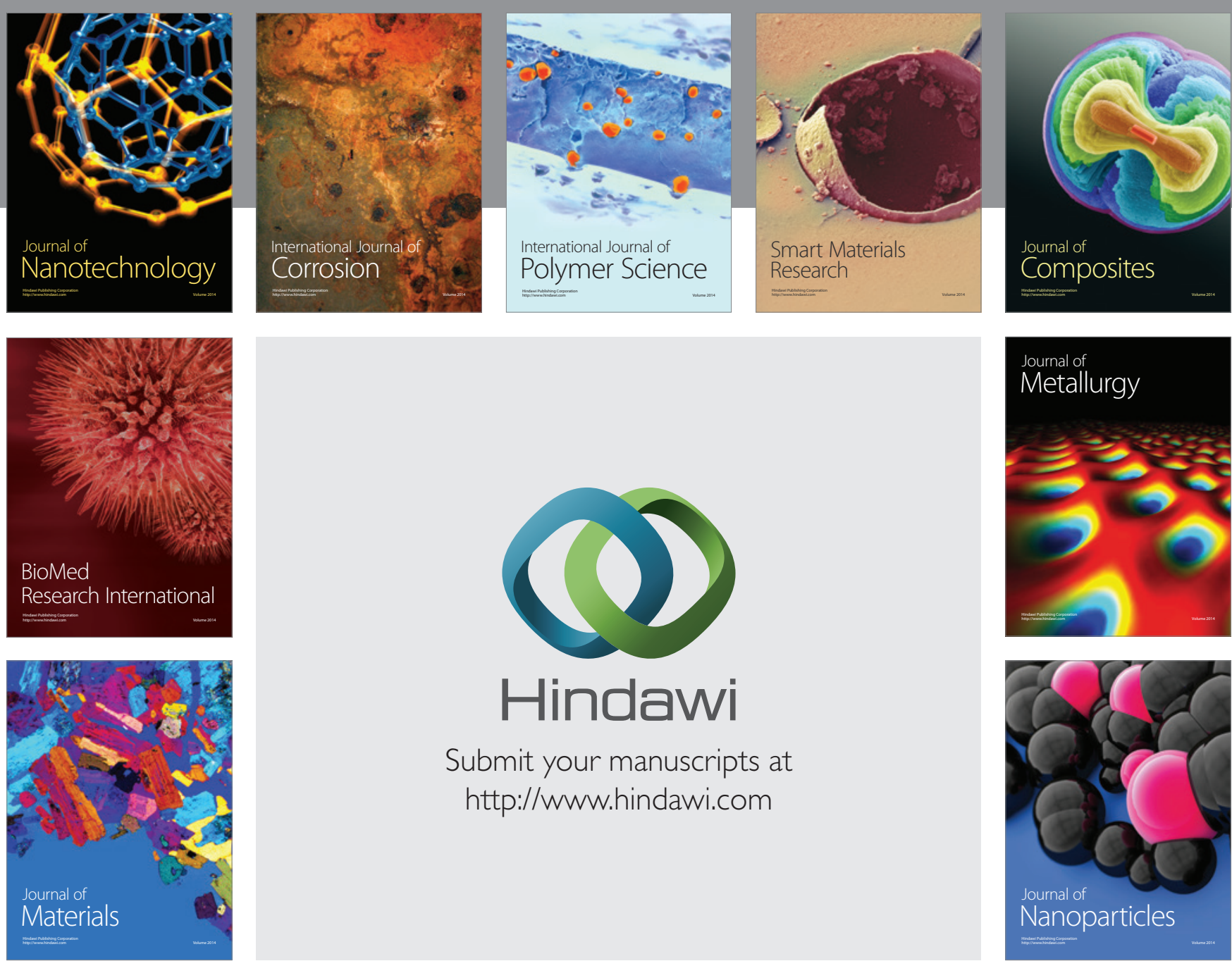

\section{Hindawi}

Submit your manuscripts at

http://www.hindawi.com

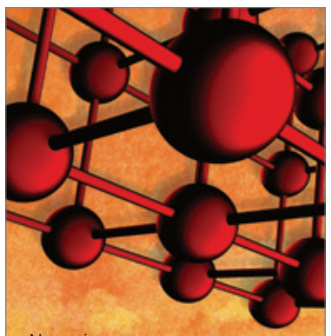

Materials Science and Engineering
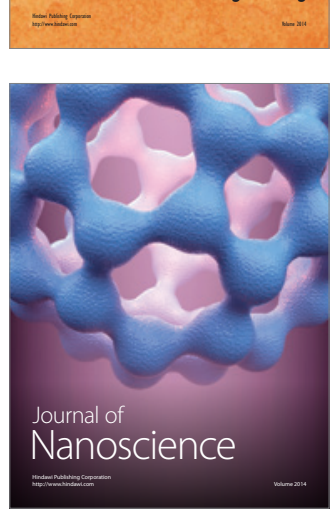
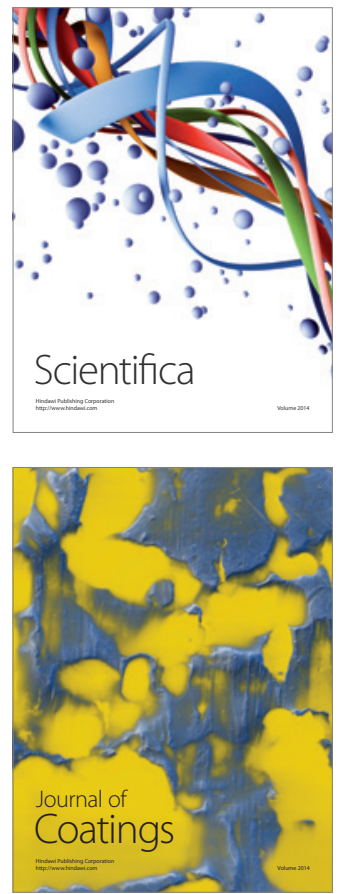
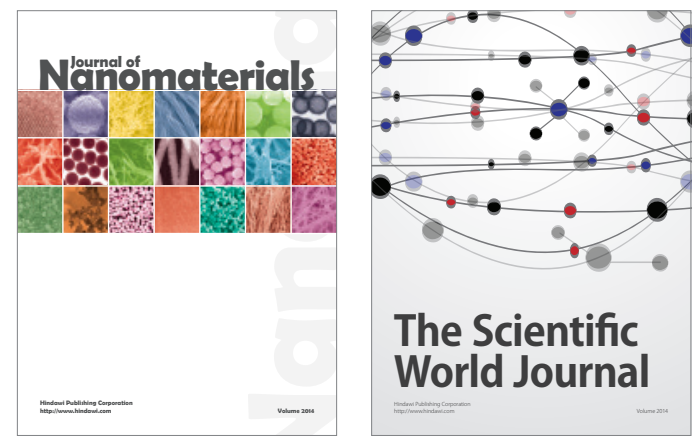

The Scientific World Journal
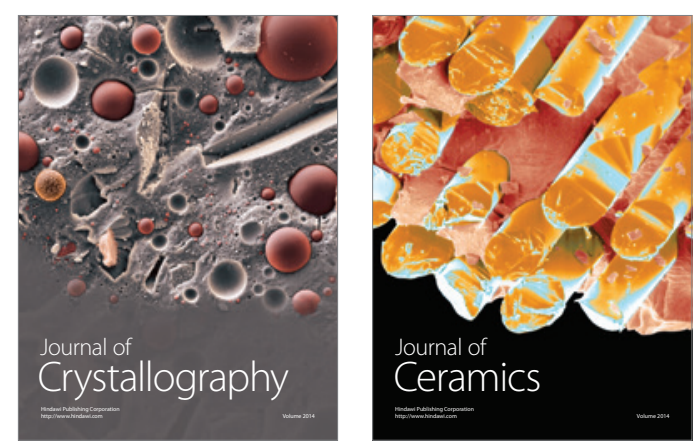
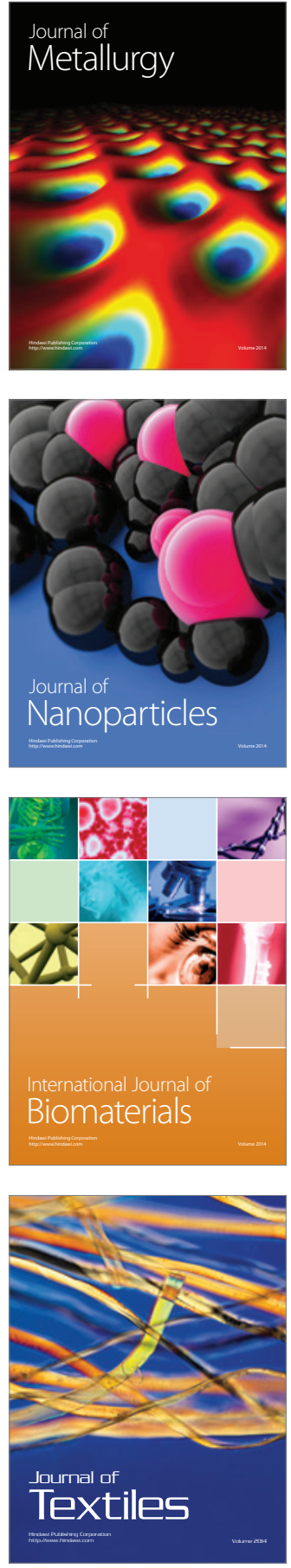